\title{
Inflammation in Periodontal Disease: Possible Link to Vascular Disease
}

\author{
Oindrila Paul', Payal Arora², Michael Mayer ${ }^{3}$ and Shampa Chatterjee ${ }^{1 *}$ \\ ${ }^{1}$ Institute for Environmental Medicine, Department of Physiology, University of Pennsylvania School of Medicine, \\ Philadelphia, PA, United States, ${ }^{2}$ Early-Research Oral Care, Colgate-Palmolive Company, Piscataway, NJ, United States, \\ ${ }^{3}$ Department of Radiology, University of Pennsylvania School of Medicine, Philadelphia, PA, United States
}

Inflammation is a well-organized protective response to pathogens and consists of immune cell recruitment into areas of infection. Inflammation either clears pathogens and gets resolved leading to tissue healing or remains predominantly unresolved triggering pathological processes in organs. Periodontal disease (PD) that is initiated by specific bacteria also triggers production of inflammatory mediators. These processes lead to loss of tissue structure and function. Reactive oxygen species and oxidative stress play a role in susceptibility to periodontal pathogenic bacterial infections. Periodontal inflammation is a risk factor for systemic inflammation and eventually cardiovascular disease (CVD). This review discusses the role of inflammation in PD and its two way association with other health conditions such as diabetes and CVD. Some of the mechanisms underpinning the links between inflammation, diabetes, CVD and PD are also discussed. Finally, we review available epidemiological data and other reports to assess possible links between oral health and CVD.

\footnotetext{
Keywords: vascular inflammation, cardiovascular disease, dental plaque, risk factors, oxidative stress, antioxidants, NLRP3 inflammasome, periodontal disease (PD)
}

\section{INTRODUCTION}

Periodontal disease (PD) is a chronic inflammatory disorder characterized by the destruction of the periodontium, or the supporting tissues of the teeth (gingival tissue, periodontal ligament, and alveolar bone). PD is highly prevalent, and approximately $50 \%$ of adults 30 years and older and $70 \%$ of adults 65 or older have a form of the disease (Eke et al., 2012). Clinically, the failure to treat PD leads to loss of teeth (Schultz-Haudt et al., 1954; Hajishengallis et al., 2011; Abusleme et al., 2013). Central to PD is dysregulation of the resolution of inflammation, resulting in characteristic chronic and progressive destruction.

Inflammation is a programmed signaling event initiated to protect organisms upon infection and/or injury. In general, infection-injury stimuli lead to release of pathogen or danger associated molecular patterns (PAMPs or DAMPs) followed by their binding to respective receptors in the host cells. Although there are multiple contributing factors to $\mathrm{PD}$, one of the increasingly well-characterized triggers is the colonization of the oral cavity by pathogenic bacteria and their subsequent penetration into local epithelial lining (Darveau, 2010; Abusleme et al., 2013). This initiates an inflammatory cascade characterized by increased expression of various inflammatory mediators and adhesion molecules that collectively mobilize and recruit polymorphonuclear neutrophils (PMN), macrophages, natural killer (NK), dendritic cells (DC) etc. into the affected tissue. Under normal conditions, neutrophils and macrophages phagocytose the microbial organisms after which they undergo apoptosis at the inflamed site (Fox et al., 2010). The clearance of apoptotic 
cells facilitates a switch from a pro- to an anti-inflammatory macrophage phenotype (Fadok et al., 1998; Michlewska et al., 2009) and initiates the onset of the resolution of inflammation, a coordinated signaling process that restores tissue integrity and function. However, failure to switch off the inflammation cascade once the pathogenic stimulus is removed, leads chronic inflammation (i.e., an uncontrolled inflammatory response that can culminate into damage to the host tissue) and is the hallmark of several inflammatory disorder related pathologies. In PD specifically, the inflammatory response becomes chronic when pathogenic bacteria continue to propagate and cannot be controlled by the acute immune response, resulting in unresolved inflammation, destruction of local bone and soft tissue, and fibrosis (Cochrane, 2008).

Importantly, reports have consistently highlighted a role for periodontal inflammation in acceleration of various vascular pathologies and other systemic implications (Humphrey et al., 2008; Ogrendik, 2013; Ketabi et al., 2016). The destruction of local epithelium by PD pathogens can result in release of local inflammatory mediators from the periodontal pocket into the systemic circulation thus facilitating immune cell recruitment elsewhere. Also, bacteria can either indirectly (within immune cells that have ingested them) or directly circulate in the bloodstream (Lockhart et al., 2009). Therefore, under conditions where there is disposition (e.g., genetic, lifestyle) toward cardiovascular disease (CVD), the bacterial components and systemic inflammatory mediators can potentially accelerate plaque formation. To this point, PD pathogens have been detected in distant tissues and organs, particularly in the cardiovascular system (Okuda et al., 2001; Kozarov et al., 2006; Nakano et al., 2006; Pessi et al., 2013; Moreno et al., 2017). The relationship between PD and systemic diseases such as CVD has been increasingly well-characterized. Importantly, two classic meta-analyses demonstrated the correlation between PD and CVD, highlighting PD as a potential risk factor for CVD processes such as coronary artery disease (Janket et al., 2003; Khader et al., 2004). Additionally, recent evidence suggests a major role for reactive oxygen species (ROS) and proteolytic enzymes (bacteria- and host-derived) in PD and CVD such as atherosclerosis (Chistiakov et al., 2016).

CVD is an umbrella term for a number of linked pathologies, commonly defined as coronary heart disease (CHD), cerebrovascular disease, peripheral arterial disease, rheumatic and congenital heart diseases, and venous thromboembolism (Lara-Pezzi et al., 2012; Mandviwala et al., 2016). The associated risk factors include ethnicity, age, and family history of CVD, dyslipidemia, hypertension, tobacco smoke, excess body weight, physical inactivity, and diabetes mellitus. It is well established that these classic risk factors interact with cellular immune-inflammatory signaling processes to lead to endothelial dysfunction and atheromatous plaque development (LopezCandales et al., 2017; Lazzerini et al., 2019). Thus chronic inflammation plays a crucial role in the long-term progression of atherosclerosis. About $35-50 \%$ of the world population suffers from periodontitis as reported by World Health Organization (Petersen and Ogawa, 2012); therefore understanding any correlation or link between PD and CVD is a question that has tremendous importance given the high incidences of both diseases. This review summarizes pathophysiology of PD and examines the possibility of its link with CVD.

\section{PERIODONTAL DISEASE}

The inflammation of tissues in gingivitis and periodontitis is caused by a host of bacteria (Schultz-Haudt et al., 1954). The bacterial species present in the gingival margin are Porphyromonas gingivalis, Treponema denticola, and Tannnerella forsythia, all of which are Gram negative. Also present are Gram positive bacteria like Streptococcus sanguis, Streptococcus oralis, Streptococcus mutans, Actinomyces naeslundii, and Actinomyces odontolyticus (Abusleme et al., 2013). This is followed by appearance of secondary bacteria such as Fusobacterium nucleatum (Kolenbrander et al., 1989). Aggregates of bacterial colonies form and Gram-positive and Gram-negative bacilli become embedded in the extracellular matrix (Gibbons, 1989). Indeed more than 700 bacterial species have been reported to be detected in dental plaques (Moore, 1987; Gao et al., 2018). Bacterial species normally act as symbiotic communities with the host but shifts of the oral microbiome often associated with "poor" host health can lead to dysbiosis, an imbalance that is responsible for the development of microbe-related PD (Socransky et al., 1998; Darveau, 2010).

Several of these bacteria are also present in healthy individuals; however it is their relative abundance due to with poor oral hygiene (Hoare et al., 2019), tobacco consumption etc. that drives the selection and prevalence of pathogenic bacteria in subgingival margin that lead to the onset of periodontitis (Schultz-Haudt et al., 1954; Socransky et al., 1998). Increased oxidative stress with smoking, lifestyle diseases and aging also plays a role; indeed a strong association between oxidative stress and PD has been reported (Chapple and Matthews, 2007). This occurs either due to diminution of antioxidants or an exaggerated inflammatory response post periodontal infection. This is described in the next section. Bacterial plaque formation leads to increases in PAMPs causing a rise in local inflammation, causing increased flow of gingival crevicular fluid (GCF). This in turn provides protein rich nutrients that increase the proliferation of the Gramnegative bacteria. The dental plaque biofilm of bacteria in the periodontal crevice induces clinical signs of inflammation. The progression of PD is driven primarily by the proliferation of $P$. gingivalis which facilitates increase in harmful microbiota. The next step is the secondary bacteria $F$. nucleatum's role in the subgingival biofilm as this bacterium interacts with other bacterial species found in the biofilm. F. nucleatum serves as a bridge between the early colonizers like Streptococcus sp. and the late colonizers like $P$. gingivalis. The innate immune response is the recruitment of PMN and the NK cells that is driven by the subgingival bacterial community present in the periodontal pocket. As the microorganisms are abundant, PMN recruitment and phagocytosis is followed by extensive PMN apoptosis or necrosis. A cytokine rich proinflammatory environment consists of tumor necrosis factor (TNF)- $\alpha$, interleukins (IL)-1, IL-4, IL-10, interferon (IFN- $\gamma)$ and transforming growth factor (TGF- $\beta$ ). 
These signaling molecules stimulate the activation of enzymes and transcription factors that in turn recruit more immune cells and degrade the surrounding tissues by maintaining a continual loop of local inflammation (Cekici et al., 2014; Figure 1). This is also accompanied by an adaptive immune response as antigen uptake and processing is carried out by DC and presented to naive T cells. DCs direct CD4+ T cells to differentiate to T-cell subsets such as $\mathrm{T}$ helper cells types 1,2 , and 17 , and regulatory $\mathrm{T}$ cells (Song et al., 2018). CD4+ T cells produce the bone resorption promoting cytokine, Receptor activator of nuclear factor-кB (RANK-L; Tang et al., 2007) leading to bone loss.

\section{OXIDATIVE STRESS IN PD and CVD}

Reactive oxygen species and the resultant oxidative stress plays an important role in onset and progression of PD (Chapple and Matthews, 2007). This occurs via multiple mechanisms. First, is the ROS production that occurs with periodontal infection, as inflammatory cells are recruited to the infection site with chronic or aggressive periodontitis. Numerous reports have shown that PMN in the population diagnosed with PD generate significantly more ROS (upon stimulation) as compared to PMN of healthy controls (Aboodi et al., 2011; White et al., 2014; Ling et al., 2016). While this is indicative of a hyperreactive phenotype of neutrophils in the $\mathrm{PD}$ affected, it also suggests that high oxidative stress arising from the excessive ROS could increase local gingival oxidative stress which in turn would drive more inflammation. Alteration of the gingival crevicular environment increase susceptibility to periodontal pathogenic bacteria. Second, is the antioxidant status of PD affected individuals; several studies have shown that the low levels of anti-oxidants (that may be associated with high levels of ROS) in the GCF activated the local periodontal inflammation and caused oxidative injury and destruction of the tissue (Tsai et al., 2005; Chapple and Matthews, 2007; Konopka et al., 2007). Figure 2 shows the feed forward loop of infection induced ROS and oxidative stress that in turn drives more inflammation and changes the local gingival tissue environment making it more susceptible to infection. Lifestyle diseases also play a part in this ROS oxidative stress inflammation cascade.

As is well established, inflammation and oxidative stress are pivotal events that lead to CVD (Mandviwala et al., 2016; Cervantes Gracia et al., 2017) and seem to be the common link between the onset of tissue destruction in periodontitis and systemic inflammation (Wang et al., 2017). Indeed several lifestyle and age related conditions associated with CVD (such as diabetes, hypertension etc.) that lead to high oxidative stress (as assessed by markers of ROS and lipid peroxidation) can also increase susceptibility to PD (Dhadse et al., 2010). When periodontitis susceptible patients are exposed to the bacterial antigen, their main two immune responses in the form of neutrophil recruitment and proteolytic enzymes production further release ROS at the gingival site, thus perpetuating oxidative stress and tissue damage (Scott and Krauss, 2012; Cortes-Vieyra et al., 2016). As periodontitis progresses, periodontal inflammation produces ROS that diffuses into the blood stream (Sobaniec and Sobaniec-Lotowska, 2000; Tomofuji et al., 2007). As a result, various moieties in the blood get oxidized and induce an oxidative stress on other organs via the circulating blood causing circulating oxidative stress (Yagi, 1987; Tomofuji et al., 2007; Figure 3). Thus, it can be inferred that the bacteria present in the periodontal pocket suppress detoxification of ROS by consuming the antioxidants present in the pockets
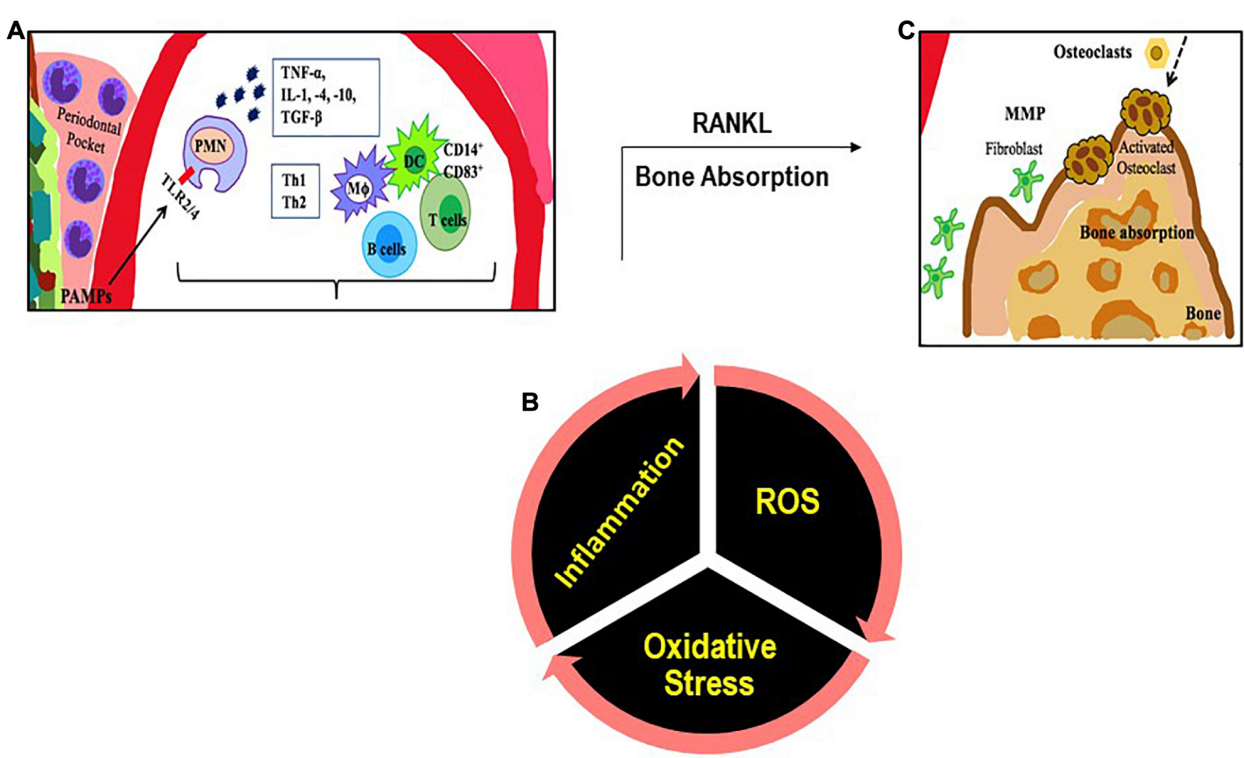

FIGURE 1 | An illustration of the inflammatory immune response with PD. (A) PAMPs (like LPS) are recognized by TLRs. The PAMP-TLR interaction triggers a proinflammatory signaling cascade that drives a chemokine and cytokine rich environment into which multiple immune cells [macrophages (M $\Phi$ ), $T$ and $B$ lymphocytes, dendritic cells (DC)] are recruited. (B) Multiple immune cells produce ROS. (C) T cells produce the cytokine RANKL that participates in bone resorption. 


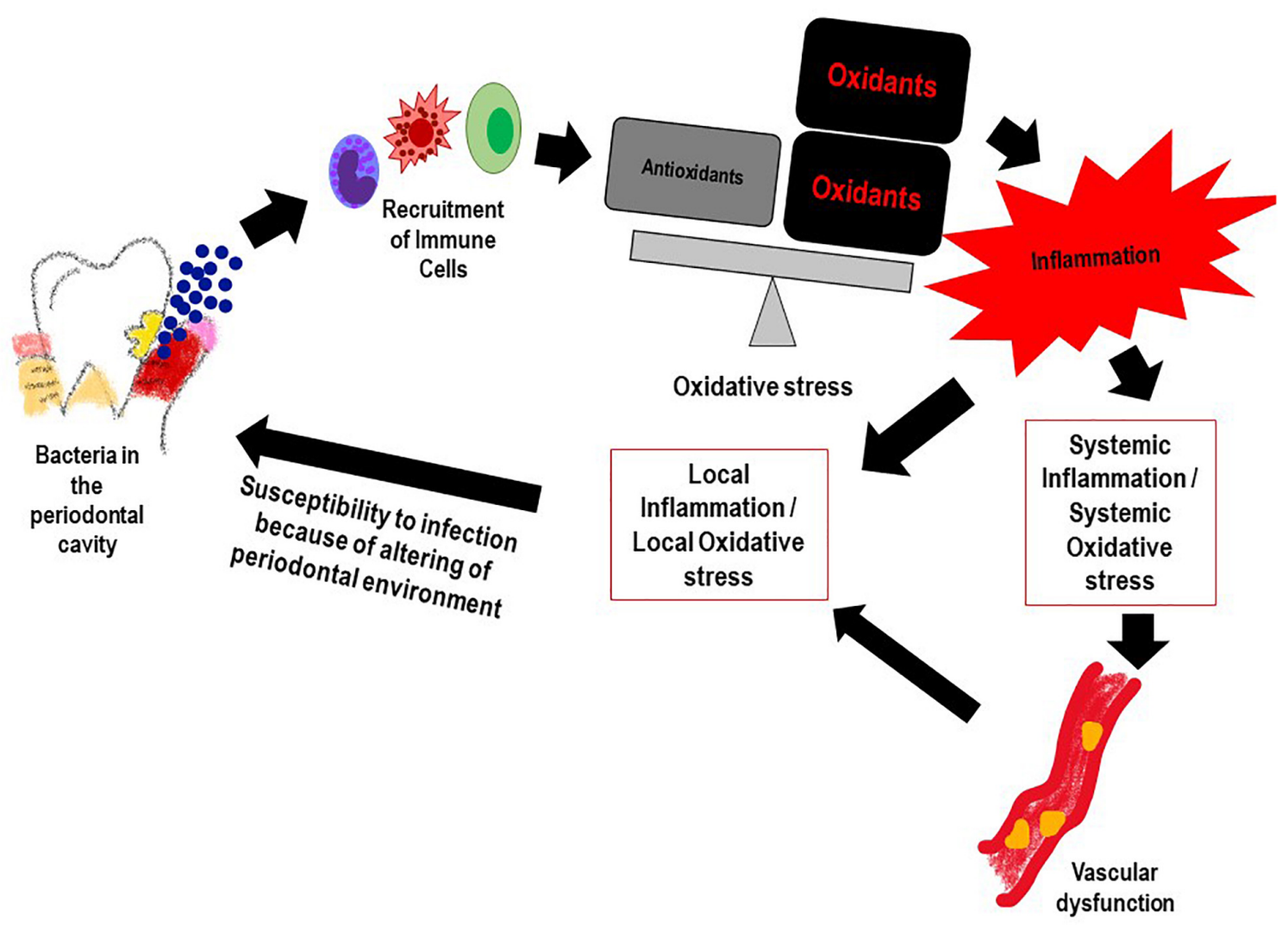

FIGURE 2 | The feed forward mechanism of the "Infection-ROS-Inflammation" triad that seems to accelerate susceptibility to infection, inflammation and oxidative stress.

of the oral cavity (Ekuni et al., 2009). The consequence of the lowered levels of antioxidants enables ROS to enter into systemic circulation from the periodontal tissues (Wang et al., 2017).

Regular smoking, diabetes mellitus, insufficient and appropriate nutrition, and aging have all been mentioned as risk factors for both PD and CVD (Yanbaeva et al., 2007; Graves and Kayal, 2008; Dhadse et al., 2010). All the above lifestyle diseases have been known to increase the circulating oxidative stress; indeed increase in levels of malondialdehyde (MDA) and 4-hydroxynonenal (HNE) locally and systemically with PD and with CVD have been observed, thus suggesting an association between local and systemic oxidative stress diseases (Celec et al., 2005; Guentsch et al., 2008; Hendek et al., 2015). Similarly, levels of antioxidants such as SOD and glutathione decrease in the (GCF) and saliva due to smoking in both, healthy individuals and patients with periodontitis (Guentsch et al., 2008; Agnihotri et al., 2009).

\section{RISK FACTORS (PD AND VASCULAR INFLAMMATION)}

Vascular inflammation involves the onset of a signaling cascade that is triggered by endothelial signaling which leads to increase in cellular adhesions molecules, cytokines and chemokines. This leads to recruitment and adherence of immune cells. The atherogenic process starts with endothelial dysfunction and the accumulation of several plasma low density lipoproteins (LDL) in the subendothelial space. The accumulation of LDL correlates with classical risk factors, such as smoking, hypertension, and metabolic dysregulation in obesity and diabetes mellitus (Gimbrone et al., 2000). As these risk factors are largely associated with $\mathrm{PD}$ too, it is reasonable to conclude that common biochemical signaling pathways play a role in vulnerability to both CVD and PD. All the major risk factors associated with $P D$ either activate pathogen initiated inflammation signals (bacteria like $P$. gingivalis and $A$. actinomycetemcomitans $B$. forsythus, $P$. intermedia, P. micros, and F. nucleatum (Lovegrove, 2004; Saito et al., 2008) or a life style (diabetes mellitus, obesity, aging, smoking, vascular disease) driven inflammatory cascade (Jensen et al., 1991; Grossi and Genco, 1998; Cohen, 2000; Merchant et al., 2003; Humphrey et al., 2008; Hujoel, 2009; Kumar et al., 2011; Nakamura et al., 2011; Ozcaka et al., 2011). Nutrition and oral health are closely linked. This is because oxidative stress and antioxidant balance which drives ROS induced inflammation signals, can be regulated by diets rich in antioxidants (Muniz et al., 2015). Diets that lead to obesity such as high carbohydrates and sugars have been implicated in dental caries and PD as these drive plaque formation and 


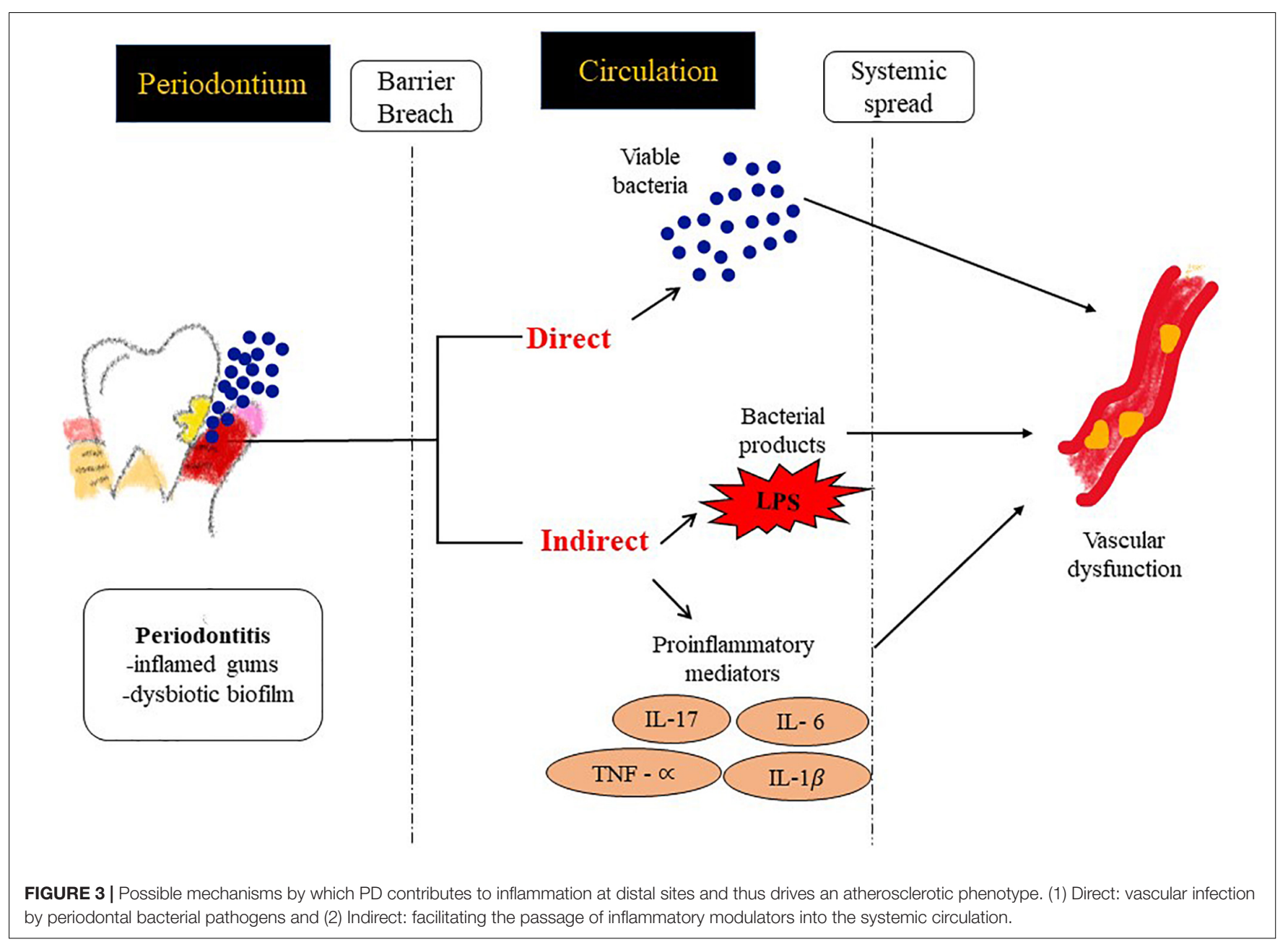

accelerate inflammation thus causing dental tissue oxidative damage and decay (Hujoel, 2009). Changes in dietary intake influence the extent of PD. As seen in the dietary intake of adolescents between 11 and 18 years old, the decrease in consumption of raw fruits and non-potato vegetables with concomitant increase in uptake of soft drinks, led to increased PD (Chaffee and Weston, 2010).

Indeed when all these risk factors are controlled, both PD and CVD show improvement (Table 1; Higashi et al., 2008; Bokhari et al., 2012; Montenegro et al., 2019; Lobo et al., 2020).

\section{PD AND CVD: IS THERE A LINK?}

It is not clear if there is a direct and common thread between PD and CVD; however the fact that people with PD have a two or three times higher risk of a cardiovascular event (stroke, heart attack etc.) seems to point to a cluster of shared risk factors between the two (Sanz et al., 2020). The "inflammation" link seems to be a key contributor to both.

For instance, when infected with $P$. gingivalis, the host innate immune system responds by activating inflammation consisting of the NLRP3 inflammasome (pro-inflammatory IL-1 $\beta$, IL-18) (Lamkanfi and Dixit, 2009; Xue et al., 2015). Patients with chronic PD and aggressive PD expressed significantly higher levels of NLRP3 in gingiva (Xue et al., 2015; Ran et al., 2017). In wild type mice with $P$. gingivalis infection, the increase in expression of NLRP3 inflammation cascade in the gingival tissue was matched with a concomitant increase in caspase- 1 activity in the macrophages found in peritoneum; this was not observed in NLRP3 deficient mice (Yamaguchi et al., 2017). This suggests that the NLRP3 inflammasome activated in periodontitis has effects on the systemic organs. NLRP3 inflammasome has also been shown to be highly expressed and activated with systemic vascular disease (Satoh et al., 2014) although it is not clear whether NLRP3 from P. gingivalis (Yamaguchi et al., 2017) is directly involved. However, excess ROS, glucose, ATP, ceramides, sphingosine, cholesterol crystals, uric acid and oxidized LDL (all of which are associated with CVD) have been known to activate NLRP3 inflammasome (Duewell et al., 2010; Jiang et al., 2012; Luheshi et al., 2012).

Epidemiologic data till date that suggest an association between PD and CVD (Humphrey et al., 2008; Blaizot et al., 2009; Tonetti, 2009) have monitored PD via indices of clinical 
TABLE 1 | Clinical trials investigating relationship between periodontal disease and cardiovascular disease.

\begin{tabular}{|c|c|c|c|c|}
\hline Citation & Aims & Patients & Cohorts & Outcomes \\
\hline Elter et al., 2006 & $\begin{array}{l}\text { Effect of periodontal treatment on } \\
\text { endothelium-dependent flow-mediated dilation } \\
\text { and serum inflammatory biomarkers in patients } \\
\text { with PD }\end{array}$ & $\begin{array}{l}\text { Twent-two male } \\
\text { patients with PD }\end{array}$ & $\begin{array}{l}\text { All patients underwent periodontal } \\
\text { treatment (scaling and root planning, } \\
\text { periodontal flap surgery if indicated, } \\
\text { and extraction of hopeless teeth) }\end{array}$ & $\begin{array}{l}\text { Periodontal treatment resulted in significant improvements } \\
\text { in flow-mediated dilation and decreased serum IL-6 (and a } \\
\text { trend toward reduction in CRP) }\end{array}$ \\
\hline D’Aiuto et al., 2006 & $\begin{array}{l}\text { Effects of intensive periodontal treatment on } \\
\text { serum inflammatory biomarkers, serum lipid } \\
\text { levels, and blood pressure in patients with PD }\end{array}$ & $\begin{array}{l}\text { Forty patients with } \\
\text { severe PD }\end{array}$ & $\begin{array}{l}\text { - Experimental group: subject to } \\
\text { intensive periodontal treatment (defined } \\
\text { as standard treatment plus adjunctive } \\
\text { use of a locally delivered antimicrobial) } \\
\text { - Control group: standard periodontal } \\
\text { treatment (scaling and root planning) }\end{array}$ & $\begin{array}{l}\text { Intensive periodontal treatment resulted in significant } \\
\text { reduction in IL-6, CRP, total cholesterol, and systolic blood } \\
\text { pressure at 2-month follow-up }\end{array}$ \\
\hline Tonetti et al., 2007 & $\begin{array}{l}\text { To investigate the effects of periodontal } \\
\text { treatment on parameters of endothelial function } \\
\text { in patients with PD }\end{array}$ & $\begin{array}{l}\text { Hundred and } \\
\text { twnety patients } \\
\text { with severe PD }\end{array}$ & $\begin{array}{l}\text { - Experimental group: subject to } \\
\text { intensive PD treatment } \\
\text { - Control group: subject to } \\
\text { community-based periodontal care }\end{array}$ & $\begin{array}{l}\text { Intensive periodontal treatment resulted in reduced brachial } \\
\text { artery flow, reduced levels of CRP and IL-6, and elevated } \\
\text { endothelial-activation markers.- Intensive treatment was } \\
\text { associated with reduced indexes of periodontal disease } \\
\text { severity and significantly better endothelial function at } 6 \\
\text { month follow-up }\end{array}$ \\
\hline Higashi et al., 2008 & $\begin{array}{l}\text { To evaluate endothelial function in patients with } \\
\text { hypertension and PD }\end{array}$ & $\begin{array}{l}\text { Sixty-four patients } \\
\text { with hypertension } \\
(26 \text { with PD and } 38 \\
\text { without PD) }\end{array}$ & $\begin{array}{l}\text { - Experimental group: subject to } \\
\text { periodontal treatment } \\
\text { - Control group: subject to } \\
\text { community-based periodontal care }\end{array}$ & $\begin{array}{l}\text { Periodontal treatment resulted in decreased serum CRP } \\
\text { and IL-6 at 24-week follow-up } \\
\text { Periodontal treatment resulted in reduced } \\
\text { acetylcholine-stimulated vasodilation } \\
\text { Delivery of a nitric oxide synthase inhibitor before and after } \\
\text { PD treatment resulted in similar acetylcholine-stimulated } \\
\text { vasodilation, suggesting role of nitric oxide bioavailability in } \\
\text { mechanism of endothelial dysfunction in patients with PD }\end{array}$ \\
\hline Higashi et al., 2009 & $\begin{array}{l}\text { To evaluate endothelial function and the effects } \\
\text { of periodontal treatment on patients with CAD } \\
\text { and PD }\end{array}$ & $\begin{array}{l}101 \text { patients with } \\
\text { CAD ( } 48 \text { with } P D \\
\text { and } 53 \text { without } P D)\end{array}$ & $\begin{array}{l}\text { - Experimental group: subject to } \\
\text { periodontal treatment } \\
\text { - Control group: subject to } \\
\text { community-based periodontal care }\end{array}$ & $\begin{array}{l}\text { - Periodontal treatment resulted in decreased serum CRP } \\
\text { and IL-6 at follow-up } \\
\text { - Periodontal treatment resulted in reduced } \\
\text { acetylcholine-stimulated vasodilation } \\
\text { - Delivery of a nitric oxide synthase inhibitor before and after } \\
\text { PD treatment resulted in similar acetylcholine-stimulated } \\
\text { vasodilation, suggesting role of nitric oxide bioavailability in } \\
\text { mechanism of endothelial dysfunction in patients with PD }\end{array}$ \\
\hline $\begin{array}{l}\text { Offenbacher et al., } \\
2009\end{array}$ & $\begin{array}{l}\text { Impact of periodontal treatment on serum CRP } \\
\text { levels, clinical PD parameters, and } \\
\text { cardiovascular endpoints in patients with PD }\end{array}$ & $\begin{array}{l}\text { Three hundred } \\
\text { three patients with } \\
\text { PD and previous } \\
\text { history of CVD }\end{array}$ & $\begin{array}{l}\text { - Experimental group: subject to } \\
\text { periodontal treatment (scaling and root } \\
\text { planning } \\
\text { - Control group: not subject to } \\
\text { periodontal treatment }\end{array}$ & $\begin{array}{l}\text { Periodontal treatment resulted in a significant improvement } \\
\text { in PD status at } 6 \text { months as assessed by reduction of } \\
\text { probing depth, but no difference in attachment levels, } \\
\text { bleeding upon probing, or extent of subgingival calculus } \\
\text { Periodontal treatment resulted in significant decrease of the } \\
\text { odds of being in the high-risk ( }>3 \mathrm{mg} / \mathrm{L} \text { ) CRP group at } \\
6 \text { months, with obesity nullifying such effect }\end{array}$ \\
\hline
\end{tabular}




\begin{tabular}{|c|c|c|c|c|}
\hline Citation & Aims & Patients & Cohorts & Outcomes \\
\hline Vidal et al., 2009 & $\begin{array}{l}\text { Effects of non-surgical PD treatment on plasma } \\
\text { levels of inflammatory markers (interleukin [LL]-6, } \\
\text { C-reactive protein [CRP], and fibrinogen) in } \\
\text { patients with severe PD and refractory arterial } \\
\text { hypertension }\end{array}$ & $\begin{array}{l}\text { Twenty-two } \\
\text { patients with severe } \\
\text { PD and refractory } \\
\text { arterial } \\
\text { hypertension }\end{array}$ & $\begin{array}{l}\text { - Experimental group: subject to } \\
\text { periodontal treatment at start of trial } \\
\text { - Control group: subject to periodontal } \\
\text { treatment delayed 3-months from start } \\
\text { of trial }\end{array}$ & $\begin{array}{l}\text { Periodontal treatment resulted in significant reduction in } \\
\text { markers of PD severity (probing, probing depth, and clinical } \\
\text { attachment loss) } \\
\text { Periodontal treatment resulted in significant reduction of } \\
\text { fibrinogen, CRP, and IL-6 }\end{array}$ \\
\hline $\begin{array}{l}\text { Wehmeyer et al., } \\
2013\end{array}$ & $\begin{array}{l}\text { Impact of periodontal treatment PD parameters } \\
\text { and inflammatory biomarkers in patients with } \\
\text { end-stage renal disease and PD }\end{array}$ & $\begin{array}{l}\text { Three hundred } \\
\text { forty-two dialysis } \\
\text { patients with } \\
\text { moderate/severe } \\
\text { chronic PD }\end{array}$ & $\begin{array}{l}\text { - Experimental group: subject to } \\
\text { intensive periodontal treatment } \\
\text { - Control group: subject to intensive } \\
\text { periodontal treatment following study } \\
\text { completion at } 6 \text { months }\end{array}$ & $\begin{array}{l}\text { Intensive periodontal treatment resulted in significantly } \\
\text { improved measures of periodontal health at } 3 \text { months, but } \\
\text { only PD remained significantly different at } 6 \text { months } \\
\text { No significant difference between the groups inflammatory } \\
\text { biomarkers (serum albumin or high-sensitivity interleukin 6) } \\
\text { at any time point }\end{array}$ \\
\hline Bokhari et al., 2012 & $\begin{array}{l}\text { Effect of non-surgical periodontal treatment on } \\
\text { systemic C-reactive protein, fibrinogen and } \\
\text { white blood cells in coronary heart disease } \\
\text { patients with PD }\end{array}$ & $\begin{array}{l}\text { Three hundred } \\
\text { seventeen } \\
\text { patientswith } \\
\text { angiographically } \\
\text { proven coronary } \\
\text { heart disease }\end{array}$ & $\begin{array}{l}\text { - Experimental group: subject to } \\
\text { on-surgical periodontal treatment } \\
\text { (scaling, root planning and oral hygiene } \\
\text { instructions) } \\
\text { - Control group: not subject to } \\
\text { periodontal treatment }\end{array}$ & $\begin{array}{l}\text { Non-surgical periodontal treatment resulted in significant } \\
\text { reduction of systemic levels of inflammatory markers (CRP, } \\
\text { fibrinogen and WBCs) at 2-month follow-up }\end{array}$ \\
\hline Caula et al., 2014 & $\begin{array}{l}\text { Influence of non-surgical mechanical PD } \\
\text { treatment on c-reactive protein serum level, } \\
\text { erythrocyte sedimentation rate (ESR), and lipid } \\
\text { profile in patients with severe chronic } \\
\text { periodontitis }\end{array}$ & $\begin{array}{l}\text { Sixty-four patients } \\
\text { with severe chronic } \\
\text { PD }\end{array}$ & $\begin{array}{l}\text { - Experimental group: Began } \\
\text { non-surgical PD treatment } \\
\text { - Control group: Withheld PD treatment } \\
\text { during study period }\end{array}$ & $\begin{array}{l}\text { PD treatment resulted in a significant reduction of ESR and } \\
\text { triglycerides at } 2 \text { months } \\
\text { PD treatment resulted in significant reduction in median } \\
\text { values of C-reactive protein, ESR, total cholesterol, and } \\
\text { triglycerides after } 6 \text { months }\end{array}$ \\
\hline Zhou et al., 2017 & $\begin{array}{l}\text { To investigate if intensive periodontal treatment } \\
\text { can lower blood pressure levels and endothelial } \\
\text { microparticles (EMPs) in patients with } \\
\text { prehypertension and PD without } \\
\text { antihypertensive medication }\end{array}$ & $\begin{array}{l}\text { Hundred and seven } \\
\text { patients with } \\
\text { prehypertension } \\
\text { and PD }\end{array}$ & $\begin{array}{l}\text { - Experimental group: Subject to } \\
\text { intensive periodontal treatment } \\
\text { - Control group: Subject to } \\
\text { community-based periodontal care }\end{array}$ & $\begin{array}{l}\text { Intensive periodontal treatment resulted in reduced clinical } \\
\text { PD parameters, reduced systolic and diastolic blood } \\
\text { pressures, and reduced endothelial microparticles }\end{array}$ \\
\hline $\begin{array}{l}\text { Montenegro et al., } \\
2019\end{array}$ & $\begin{array}{l}\text { To assess the effect of periodontal treatment on } \\
\text { clinical PD parameters and levels of } \\
\text { cardiovascular risk biomarkers in stable } \\
\text { coronary artery disease (CAD) patients (CRP, } \\
\text { glycated hemoglobin, lipids, IL-1 } 1 \beta, \mathrm{IL}-6, \mathrm{LL}-8 \text {, } \\
\mathrm{IL}-10, \mathrm{IFN}-\gamma \text { and TNF- } \alpha \text { ) }\end{array}$ & $\begin{array}{l}88 \text { patients with } \\
\text { stable coronary } \\
\text { artery disease and } \\
\text { periodontitis }\end{array}$ & $\begin{array}{l}\text { - Experimental group: Subject to } \\
\text { non-surgical periodontal treatment } \\
\text { - Control group: Subject to one session } \\
\text { of plaque removal }\end{array}$ & $\begin{array}{l}\text { Periodontal treatment resulted in significantly better } \\
\text { periodontal parameters after } 3 \text { months without significant } \\
\text { differences in blood biomarkers } \\
\text { In patients with baseline high levels of CRP, periodontal } \\
\text { treatment resulted in lower levels of CRP, IL- } 6 \text { and IL-8 }\end{array}$ \\
\hline Lobo et al., 2020 & $\begin{array}{l}\text { To investigate the impact of periodontal } \\
\text { treatment on the endothelial function of patients } \\
\text { with a recent ST-segment elevation myocardial } \\
\text { infarction (STEMI), specifically looking at } \\
\text { variation of flow-mediated vasodilation (FMD) in } \\
\text { the brachial artery, inflammatory biomarkers, } \\
\text { and adverse CVD events }\end{array}$ & $\begin{array}{l}\text { Forty-eight patients } \\
\text { with PD and with } \\
\text { recent admission } \\
\text { for STEMl }\end{array}$ & $\begin{array}{l}\text { - Experimental group: subject to } \\
\text { periodontal treatment within } 2 \text { weeks of } \\
\text { STEMI } \\
\text { - Control group: not subject to } \\
\text { periodontal treatment }\end{array}$ & $\begin{array}{l}\text { Periodontal treatment significantly improved endothelial } \\
\text { function of the brachial artery without adverse clinical } \\
\text { effects over a period of } 6 \text { months } \\
\text { Inflammatory biomarkers and cardiovascular events were } \\
\text { not significantly different between both groups }\end{array}$ \\
\hline
\end{tabular}


attachment level, pocket depth, bleeding on probing and decayed-missing-filled teeth and CVD by degree and number of obstructed coronary arteries, observed an association between PD and CVDs (Ketabi et al., 2016). Table 1 shows the clinical trials which investigated the relationship between the two diseases. While risk factors as discussed in the earlier section play a crucial role in the onset of CVD, increasing number of CVD patients do not harbor the classical risk factors. Low grade infection such as in periodontal infection could be a potential cause for CVD in these cases; indeed several studies show that $\mathrm{PD}$ as a risk factor for CVD and, in particular, atherosclerosis (Bartova et al., 2014; Toregeani et al., 2016).

Potential links between $\mathrm{PD}$ and CVD could be via two mechanisms (Figure 3).

1. Systemic Inflammation: Systemic inflammatory markers such as C-reactive protein (CRP), IL-6 etc. have shown direct correlation with specific indices of CVD such as carotidintima media thickness, or MI (myocardial infarct size) (Ali et al., 2006). Chronic periodontal infection is characterized by elevation of CRP and inflammatory cytokines in the systemic circulation (Loos et al., 2000), so it is possible that systemic inflammation in patients with $\mathrm{PD}$ can potentially accelerate endothelial dysfunction, plaque buildup and CHD events.

2. Vascular Infection: There have been reports that identify bacterial species in blood after dental procedures suggesting gingiva as a portal via which oral bacterial pathogens can enter the systemic circulation (Bahrani-Mougeot et al., 2008; Lockhart et al., 2009). As a result bacteremia of dental origin seems to play a role in the appearance of bacterial endocarditis (Mang-de la Rosa et al., 2014) and periodontal bacterial components colonize human atheromatous plaques (Haraszthy et al., 2000; Fiehn et al., 2005).

\section{REFERENCES}

Aboodi, G. M., Goldberg, M. B., and Glogauer, M. (2011). Refractory periodontitis population characterized by a hyperactive oral neutrophil phenotype. J. Periodontol. 82, 726-733. doi: 10.1902/jop.2010.100508

Abusleme, L., Dupuy, A. K., Dutzan, N., Silva, N., Burleson, J. A., Strausbaugh, L. D., et al. (2013). The subgingival microbiome in health and periodontitis and its relationship with community biomass and inflammation. ISME J. 7, 1016-1025. doi: 10.1038/ismej.2012.174

Agnihotri, R., Pandurang, P., Kamath, S. U., Goyal, R., Ballal, S., Shanbhogue, A. Y., et al. (2009). Association of cigarette smoking with superoxide dismutase enzyme levels in subjects with chronic periodontitis. J. Periodontol. 80, 657-662. doi: 10.1902/jop.2009.080545

Ali, Y. S., Rembold, K. E., Weaver, B., Wills, M. B., Tatar, S., Ayers, C. R., et al. (2006). Prediction of major adverse cardiovascular events by age-normalized carotid intimal medial thickness. Atherosclerosis 187, 186-190. doi: 10.1016/j. atherosclerosis.2005.09.003

Bahrani-Mougeot, F. K., Paster, B. J., Coleman, S., Ashar, J., Barbuto, S., and Lockhart, P. B. (2008). Diverse and novel oral bacterial species in blood following dental procedures. J. Clin. Microbiol. 46, 2129-2132. doi: 10.1128/ jcm.02004-07

Bartova, J., Sommerova, P., Lyuya-Mi, Y., Mysak, J., Prochazkova, J., Duskova, J., et al. (2014). Periodontitis as a risk factor of atherosclerosis. J. Immunol. Res. 2014:636893.

\section{CONCLUSION}

While both PD and CVD have manifestations of classic inflammation, a causative link between them has not been established. However, oxidative stress arising from lifestyle diseases play a crucial role in progression of both PD and CVD, indicating that host influence in terms of an imbalance between ROS production and endogenous antioxidant levels can increase susceptibility in individuals.

Understanding how oxidative stress and inflammation overlap in PD and CVD for high risk and older populations is of great public health importance because of the high prevalence of PD. Although both these pathologies arise from the same risk factors and show a similar systemic inflammation profile, it is not clear how these diseases intersect. Therefore it cannot be concluded that therapeutic periodontal interventions can prevent heart disease or stroke. Nevertheless, controlling the overall inflammation status by implementing a good periodontal maintenance program could presumably control the progression of CVD in periodontitis patients.

\section{AUTHOR CONTRIBUTIONS}

OP drafted the article and prepared the figures. PA drafted the article. MM drafted the article and prepared the table. SC developed the concept and outline, drafted the article, and formalized the final version. All authors approved the submission.

\section{FUNDING}

Funding was provided by a Colgate Palmolive Grant (A-2019592-OC) to SC.

Blaizot, A., Vergnes, J. N., Nuwwareh, S., Amar, J., and Sixou, M. (2009). Periodontal diseases and cardiovascular events: meta-analysis of observational studies. Int. Dent. J. 59, 197-209.

Bokhari, S. A., Khan, A. A., Butt, A. K., Azhar, M., Hanif, M., Izhar, M., et al. (2012). Non-surgical periodontal therapy reduces coronary heart disease risk markers: a randomized controlled trial. J. Clin. Periodontol. 39, 1065-1074. doi: 10.1111/j.1600-051x.2012.01942.x

Caula, A. L., Lira-Junior, R., Tinoco, E. M., and Fischer, R. G. (2014). The effect of periodontal therapy on cardiovascular risk markers: a 6-month randomized clinical trial. J. Clin. Periodontol. 41, 875-882. doi: 10.1111/jcpe.12 290

Cekici, A., Kantarci, A., Hasturk, H., and Van Dyke, T. E. (2014). Inflammatory and immune pathways in the pathogenesis of periodontal disease. Periodontology 2000, 57-80. doi: 10.1111/prd.12002

Celec, P., Hodosy, J., Celecova, V., Vodrazka, J., Cervenka, T., Halcak, L., et al. (2005). Salivary thiobarbituric acid reacting substances and malondialdehydetheir relationship to reported smoking and to parodontal status described by the papillary bleeding index. Dis. Markers 21, 133-137. doi: 10.1155/2005/693 437

Cervantes Gracia, K., Llanas-Cornejo, D., and Husi, H. (2017). CVD and oxidative stress. J. Clin. Med. 6:22. doi: 10.3390/jcm6020022

Chaffee, B. W., and Weston, S. J. (2010). Association between chronic periodontal disease and obesity: a systematic review and meta-analysis. J. Periodontol. 81, 1708-1724. doi: 10.1902/jop.2010.100321 
Chapple, I. L., and Matthews, J. B. (2007). The role of reactive oxygen and antioxidant species in periodontal tissue destruction. Periodontology 2000, 160-232. doi: 10.1111/j.1600-0757.2006.00178.x

Chistiakov, D. A., Orekhov, A. N., and Bobryshev, Y. V. (2016). Links between atherosclerotic and periodontal disease. Exp. Mol. Pathol. 100, 220-235. doi: 10.1016/j.yexmp.2016.01.006

Cochrane (2008). New cochrane systematic reviews - cochrane oral health group. J. Evid. Based Dent. Pract. 8, 258-260. doi: 10.1016/j.jebdp.2008.09.001

Cohen, D. W. (2000). Periodontal medicine in the next millennium. Intl. J. Periodontics Restorative Dent. 20, 6-7.

Cortes-Vieyra, R., Rosales, C., and Uribe-Querol, E. (2016). Neutrophil functions in periodontal homeostasis. J. Immunol. Res. 2016:1396106.

D'Aiuto, F., Parkar, M., Nibali, L., Suvan, J., Lessem, J., and Tonetti, M. S. (2006). Periodontal infections cause changes in traditional and novel cardiovascular risk factors: results from a randomized controlled clinical trial. Am. Heart. J. 151, 977-984. doi: 10.1016/j.ahj.2005.06.018

Darveau, R. P. (2010). Periodontitis: a polymicrobial disruption of host homeostasis. Nat. Rev. Microbiol. 8, 481-490. doi: 10.1038/nrmicro2337

Dhadse, P., Gattani, D., and Mishra, R. (2010). The link between periodontal disease and cardiovascular disease: how far we have come in last two decades? J. Indian Soc. Periodontol. 14, 148-154. doi: 10.4103/0972-124x.75908

Duewell, P., Kono, H., Rayner, K. J., Sirois, C. M., Vladimer, G., Bauernfeind, F. G., et al. (2010). NLRP3 inflammasomes are required for atherogenesis and activated by cholesterol crystals. Nature 464, 1357-1361. doi: 10.1038/ nature 08938

Eke, P. I., Dye, B. A., Wei, L., Thornton-Evans, G. O., and Genco, R. J. (2012). Prevalence of periodontitis in adults in the United States: 2009 and 2010. J. Dent. Res. 91, 914-920. doi: 10.1177/0022034512457373

Ekuni, D., Tomofuji, T., Sanbe, T., Irie, K., Azuma, T., Maruyama, T., et al. (2009). Periodontitis-induced lipid peroxidation in rat descending aorta is involved in the initiation of atherosclerosis. J. Periodontal Res. 44, 434-442. doi: 10.1111/j. 1600-0765.2008.01122.x

Elter, J. R., Hinderliter, A. L., Offenbacher, S., Beck, J. D., Caughey, M., Brodala, N., et al. (2006). The effects of periodontal therapy on vascular endothelial function: a pilot trial. Am. Heart. J. 151:47.

Fadok, V. A., Bratton, D. L., Konowal, A., Freed, P. W., Westcott, J. Y., and Henson, P. M. (1998). Macrophages that have ingested apoptotic cells in vitro inhibit proinflammatory cytokine production through autocrine/paracrine mechanisms involving TGF-beta. PGE2, and PAF. J. Clin. Invest. 101, 890-898. doi: $10.1172 /$ jci1112

Fiehn, N. E., Larsen, T., Christiansen, N., Holmstrup, P., and Schroeder, T. V. (2005). Identification of periodontal pathogens in atherosclerotic vessels. J. Periodontol. 76, 731-736. doi: 10.1902/jop.2005.76.5.731

Fox, S., Leitch, A. E., Duffin, R., Haslett, C., and Rossi, A. G. (2010). Neutrophil apoptosis: relevance to the innate immune response and inflammatory disease. J. Innate Immunity 2, 216-227. doi: 10.1159/000284367

Gao, L., Xu, T., Huang, G., Jiang, S., Gu, Y., and Chen, F. (2018). Oral microbiomes: more and more importance in oral cavity and whole body. Protein Cell 9, 488-500. doi: 10.1007/s13238-018-0548-1

Gibbons, R. J. (1989). Bacterial adhesion to oral tissues: a model for infectious diseases. J. Dent. Res. 68, 750-760. doi: 10.1177/00220345890680050101

Gimbrone, M. A. Jr., Topper, J. N., Nagel, T., Anderson, K. R., and Garcia-Cardena, G. (2000). Endothelial dysfunction, hemodynamic forces, and atherogenesis. Ann. N. Y. Acad. Sci. 902, 230-239. doi: 10.1111/j.1749-6632.2000.tb063 18.x

Graves, D. T., and Kayal, R. A. (2008). Diabetic complications and dysregulated innate immunity. Front. Biosci. 13, 1227-1239. doi: 10.2741/2757

Grossi, S. G., and Genco, R. J. (1998). Periodontal disease and diabetes mellitus: a two-way relationship. Ann. Periodontol. 3, 51-61. doi: 10.1902/annals.1998.3. 1.51

Guentsch, A., Preshaw, P. M., Bremer-Streck, S., Klinger, G., Glockmann, E., and Sigusch, B. W. (2008). Lipid peroxidation and antioxidant activity in saliva of periodontitis patients: effect of smoking and periodontal treatment. Clin. Oral Investig. 12, 345-352. doi: 10.1007/s00784-008-0202-z

Hajishengallis, G., Liang, S., Payne, M. A., Hashim, A., Jotwani, R., Eskan, M. A., et al. (2011). Low-abundance biofilm species orchestrates inflammatory periodontal disease through the commensal microbiota and complement. Cell Host Microbe 10, 497-506. doi: 10.1016/j.chom.2011.10.006
Haraszthy, V. I., Zambon, J. J., Trevisan, M., Zeid, M., and Genco, R. J. (2000). Identification of periodontal pathogens in atheromatous plaques. J. Periodontol. 71, 1554-1560. doi: 10.1902/jop.2000.71.10.1554

Hendek, M. K., Erdemir, E. O., Kisa, U., and Ozcan, G. (2015). Effect of initial periodontal therapy on oxidative stress markers in gingival crevicular fluid, saliva, and serum in smokers and non-smokers with chronic periodontitis. J. Periodontol. 86, 273-282. doi: 10.1902/jop.2014.140338

Higashi, Y., Goto, C., Hidaka, T., Soga, J., Nakamura, S., Fujii, Y., et al. (2009). Oral infection-inflammatory pathway, periodontitis, is a risk factor for endothelial dysfunction in patients with coronary artery disease. Atherosclerosis 206, 604610. doi: 10.1016/j.atherosclerosis.2009.03.037

Higashi, Y., Goto, C., Jitsuiki, D., Umemura, T., Nishioka, K., Hidaka, T., et al. (2008). Periodontal infection is associated with endothelial dysfunction in healthy subjects and hypertensive patients. Hypertension 51, 446-453. doi: 10.1161/hypertensionaha.107.101535

Hoare, A., Soto, C., Rojas-Celis, V., and Bravo, D. (2019). Chronic Inflammation as a Link between periodontitis and carcinogenesis. Mediators Inflamm. 2019:1029857.

Hujoel, P. (2009). Dietary carbohydrates and dental-systemic diseases. J. Dent. Res. 88, 490-502. doi: 10.1177/0022034509337700

Humphrey, L. L., Fu, R., Buckley, D. I., Freeman, M., and Helfand, M. (2008). Periodontal disease and coronary heart disease incidence: a systematic review and meta-analysis. J. Gen. Intern. Med. 23, 2079-2086. doi: 10.1007/s11606008-0787-6

Janket, S. J., Baird, A. E., Chuang, S. K., and Jones, J. A. (2003). Meta-analysis of periodontal disease and risk of coronary heart disease and stroke. Oral Surg. Oral Med. Oral Pathol. Oral Radiol. Endod. 95, 559-569. doi: 10.1067/moe.2003. 107

Jensen, J. A., Goodson, W. H., Hopf, H. W., and Hunt, T. K. (1991). Cigarette smoking decreases tissue oxygen. Arch. Surg. 126, 1131-1134. doi: 10.1001/ archsurg.1991.01410330093013

Jiang, Y., Wang, M., Huang, K., Zhang, Z., Shao, N., Zhang, Y., et al. (2012). Oxidized low-density lipoprotein induces secretion of interleukin-1beta by macrophages via reactive oxygen species-dependent NLRP3 inflammasome activation. Biochem. Biophys. Res. Commun. 425, 121-126. doi: 10.1016/j.bbrc. 2012.07.011

Ketabi, M., Meybodi, F. R., and Asgari, M. R. (2016). The association between periodontal disease parameters and severity of atherosclerosis. Dent. Res. J. 13, 250-255. doi: 10.4103/1735-3327.182185

Khader, Y. S., Albashaireh, Z. S., and Alomari, M. A. (2004). Periodontal diseases and the risk of coronary heart and cerebrovascular diseases: a meta-analysis. J. Periodontol. 75, 1046-1053. doi: 10.1902/jop.2004.75.8.1046

Kolenbrander, P. E., Andersen, R. N., and Moore, L. V. (1989). Coaggregation of Fusobacterium nucleatum, Selenomonas flueggei, Selenomonas infelix, Selenomonas noxia, and selenomonas sputigena with strains from 11 genera of oral bacteria. Infect. Immun. 57, 3194-3203. doi: 10.1128/iai.57.10.3194-3203. 1989

Konopka, T., Krol, K., Kopec, W., and Gerber, H. (2007). Total antioxidant status and 8-hydroxy-2'-deoxyguanosine levels in gingival and peripheral blood of periodontitis patients. Arch. Immunol. Ther. Exp. 55, 417-422. doi: 10.1007/ s00005-007-0047-1

Kozarov, E., Sweier, D., Shelburne, C., Progulske-Fox, A., and Lopatin, D. (2006). Detection of bacterial DNA in atheromatous plaques by quantitative PCR. Microbes Infect. 8, 687-693. doi: 10.1016/j.micinf.2005.09.004

Kumar, P. S., Matthews, C. R., Joshi, V., De Jager, M., and Aspiras, M. (2011). Tobacco smoking affects bacterial acquisition and colonization in oral biofilms. Infect. Immun. 79, 4730-4738. doi: 10.1128/iai.05371-11

Lamkanfi, M., and Dixit, V. M. (2009). Inflammasomes: guardians of cytosolic sanctity. Immunol. Rev. 227, 95-105. doi: 10.1111/j.1600-065x.2008.00730.x

Lara-Pezzi, E., Dopazo, A., and Manzanares, M. (2012). Understanding cardiovascular disease: a journey through the genome (and what we found there). Dis. Models Mech. 5, 434-443. doi: 10.1242/dmm.009787

Lazzerini, P. E., Hamilton, R. M., and Boutjdir, M. (2019). Editorial: cardioimmunology: inflammation and immunity in cardiovascular disease. Front. Cardiovasc. Med. 6:181.

Ling, M. R., Chapple, I. L., and Matthews, J. B. (2016). Neutrophil superoxide release and plasma C-reactive protein levels pre- and post-periodontal therapy. J. Clin. Periodontol. 43, 652-658. doi: 10.1111/jcpe.12575 
Lobo, M. G., Schmidt, M. M., Lopes, R. D., Dipp, T., Feijo, I. P., Schmidt, K. E. S., et al. (2020). Treating periodontal disease in patients with myocardial infarction: a randomized clinical trial. Eur. J. Intern. Med. 71, 76-80. doi: 10.1016/j.ejim.2019.08.012

Lockhart, P. B., Brennan, M. T., Thornhill, M., Michalowicz, B. S., Noll, J., BahraniMougeot, F. K., et al. (2009). Poor oral hygiene as a risk factor for infective endocarditis-related bacteremia. J. Am. Dent. Assoc. 140, 1238-1244. doi: 10 14219/jada.archive.2009.0046

Loos, B. G., Craandijk, J., Hoek, F. J., Wertheim-Van Dillen, P. M., and Van Der Velden, U. (2000). Elevation of systemic markers related to cardiovascular diseases in the peripheral blood of periodontitis patients. J. Periodontol. 71, 1528-1534. doi: 10.1902/jop.2000.71.10.1528

Lopez-Candales, A., Hernandez Burgos, P. M., Hernandez-Suarez, D. F., and Harris, D. (2017). Linking chronic inflammation with cardiovascular disease: from normal aging to the metabolic syndrome. J. Nat. Sci. 3:e341.

Lovegrove, J. M. (2004). Dental plaque revisited: bacteria associated with periodontal disease. J. N. Z. Soc. Periodontol. 2004, 7-21.

Luheshi, N. M., Giles, J. A., Lopez-Castejon, G., and Brough, D. (2012). Sphingosine regulates the NLRP3-inflammasome and IL-1beta release from macrophages. Eur. J. Immunol. 42, 716-725. doi: 10.1002/eji.201142079

Mandviwala, T., Khalid, U., and Deswal, A. (2016). Obesity and cardiovascular disease: a risk factor or a risk marker? Curr. Atheroscler. Rep. 18:21.

Mang-de la Rosa, M. R., Castellanos-Cosano, L., Romero-Perez, M. J., and Cutando, A. (2014). The bacteremia of dental origin and its implications in the appearance of bacterial endocarditis. Med. Oral Patol. Oral Cir. Bucal 19, e67-e74.

Merchant, A. T., Pitiphat, W., Ahmed, B., Kawachi, I., and Joshipura, K. (2003). A prospective study of social support, anger expression and risk of periodontitis in men. J. Am. Dent. Assoc. 134, 1591-1596. doi: 10.14219/jada.archive.2003.0104

Michlewska, S., Dransfield, I., Megson, I. L., and Rossi, A. G. (2009). Macrophage phagocytosis of apoptotic neutrophils is critically regulated by the opposing actions of pro-inflammatory and anti-inflammatory agents: key role for TNFalpha. FASEB J. 23, 844-854. doi: 10.1096/fj.08-121228

Montenegro, M. M., Ribeiro, I. W. J., Kampits, C., Saffi, M. A. L., Furtado, M. V., Polanczyk, C. A., et al. (2019). Randomized controlled trial of the effect of periodontal treatment on cardiovascular risk biomarkers in patients with stable coronary artery disease: preliminary findings of 3 months. J. Clin. Periodontol. 46, 321-331. doi: 10.1111/jcpe. 13085

Moore, W. E. (1987). Microbiology of periodontal disease. J. Periodontal Res. 22, 335-341. doi: 10.1111/j.1600-0765.1987.tb01595.x

Moreno, S., Parra, B., Botero, J. E., Moreno, F., Vasquez, D., Fernandez, H., et al. (2017). Periodontal microbiota and microorganisms isolated from heart valves in patients undergoing valve replacement surgery in a clinic in Cali, Colombia. Biomedica 37, 516-525. doi: 10.7705/biomedica.v37i4.3232

Muniz, F. W., Nogueira, S. B., Mendes, F. L., Rosing, C. K., Moreira, M. M., De Andrade, G. M., et al. (2015). The impact of antioxidant agents complimentary to periodontal therapy on oxidative stress and periodontal outcomes: a systematic review. Arch. Oral. Biol. 60, 1203-1214. doi: 10.1016/j.archoralbio. 2015.05.007

Nakamura, Y., Tagusari, O., Seike, Y., Ito, Y., Saito, K., Miyamoto, R., et al. (2011). Prevalence of periodontitis and optimal timing of dental treatment in patients undergoing heart valve surgery. Interact. Cardiovasc. Thorac. Surg. 12, 696-700. doi: $10.1510 /$ icvts. 2010.255943

Nakano, K., Inaba, H., Nomura, R., Nemoto, H., Takeda, M., Yoshioka, H., et al. (2006). Detection of cariogenic Streptococcus mutans in extirpated heart valve and atheromatous plaque specimens. J. Clin. Microbiol. 44, 3313-3317. doi: $10.1128 / \mathrm{jcm} .00377-06$

Offenbacher, S., Beck, J. D., Moss, K., Mendoza, L., Paquette, D. W., Barrow, D. A., et al. (2009). Results from the Periodontitis and Vascular Events (PAVE) Study: a pilot multicentered, randomized, controlled trial to study effects of periodontal therapy in a secondary prevention model of cardiovascular disease. J. Periodontol. 80, 190-201. doi: 10.1902/jop.2009.080007

Ogrendik, M. (2013). Rheumatoid arthritis is an autoimmune disease caused by periodontal pathogens. Intl. J. Gen. Med. 6, 383-386. doi: 10.2147/ijgm.s45929

Okuda, K., Ishihara, K., Nakagawa, T., Hirayama, A., and Inayama, Y. (2001). Detection of Treponema denticola in atherosclerotic lesions. J. Clin. Microbiol. 39, 1114-1117. doi: $10.1128 /$ jcm.39.3.1114-1117.2001
Ozcaka, O., Bicakci, N., Pussinen, P., Sorsa, T., Kose, T., and Buduneli, N. (2011). Smoking and matrix metalloproteinases, neutrophil elastase and myeloperoxidase in chronic periodontitis. Oral Dis. 17, 68-76. doi: 10.1111/ j.1601-0825.2010.01705.x

Pessi, T., Karhunen, V., Karjalainen, P. P., Ylitalo, A., Airaksinen, J. K., Niemi, M., et al. (2013). Bacterial signatures in thrombus aspirates of patients with myocardial infarction. Circulation 127:e1-6.

Petersen, P. E., and Ogawa, H. (2012). The global burden of periodontal disease: towards integration with chronic disease prevention and control. Periodontology 60, 15-39. doi: 10.1111/j.1600-0757.2011.00 425.x

Ran, S., Liu, B., Gu, S., Sun, Z., and Liang, J. (2017). Analysis of the expression of NLRP3 and AIM2 in periapical lesions with apical periodontitis and microbial analysis outside the apical segment of teeth. Arch. Oral. Biol. 78, 39-47. doi: 10.1016/j.archoralbio.2017.02.006

Saito, Y., Fujii, R., Nakagawa, K. I., Kuramitsu, H. K., Okuda, K., and Ishihara, K. (2008). Stimulation of Fusobacterium nucleatum biofilm formation by Porphyromonas gingivalis. Oral Microbiol. Immunol. 23, 1-6. doi: 10.1111/j. 1399-302x.2007.00380.x

Sanz, M., Marco Del, Castillo, A., Jepsen, S., Gonzalez-Juanatey, J. R., D’aiuto, F., et al. (2020). Periodontitis and cardiovascular diseases: consensus report. J. Clin. Periodontol. 47, 268-288.

Satoh, M., Tabuchi, T., Itoh, T., and Nakamura, M. (2014). NLRP3 inflammasome activation in coronary artery disease: results from prospective and randomized study of treatment with atorvastatin or rosuvastatin. Clin. Sci. 126, 233-241. doi: $10.1042 / \operatorname{cs} 20130043$

Schultz-Haudt, S., Bibby, B. G., and Bruce, M. A. (1954). Tissue-destructive products of gingival bacteria from nonspecific gingivitis. J. Dent. Res. 33, 624-631. doi: 10.1177/00220345540330050601

Scott, D. A., and Krauss, J. (2012). Neutrophils in periodontal inflammation. Front. Oral Biol. 15, 56-83. doi: 10.1159/000329672

Sobaniec, H., and Sobaniec-Lotowska, M. E. (2000). Morphological examinations of hard tissues of periodontium and evaluation of selected processes of lipid peroxidation in blood serum of rats in the course of experimental periodontitis. Med. Sci. Monit. 6, 875-881.

Socransky, S. S., Haffajee, A. D., Cugini, M. A., Smith, C., et al. (1998). Microbial complexes in subgingival plaque. J. Clin. Periodontol. 25, 134-144. doi: 10.1111/ j.1600-051x.1998.tb02419.x

Song, L., Dong, G., Guo, L., and Graves, D. T. (2018). The function of dendritic cells in modulating the host response. Mol. Oral Microbiol. 33, 13-21. doi: 10.1111/omi.12195

Tang, D., Shi, Y., Kang, R., Li, T., Xiao, W., Wang, H., et al. (2007). Hydrogen peroxide stimulates macrophages and monocytes to actively release HMGB1. J. Leukoc. Biol. 81, 741-747. doi: 10.1189/jlb.0806540

Tomofuji, T., Ekuni, D., Yamanaka, R., Kusano, H., Azuma, T., Sanbe, T., et al. (2007). Chronic administration of lipopolysaccharide and proteases induces periodontal inflammation and hepatic steatosis in rats. J. Periodontol. 78, 1999-2006. doi: 10.1902/jop.2007.070056

Tonetti, M. S. (2009). Periodontitis and risk for atherosclerosis: an update on intervention trials. J. Clin. Periodontol. 36(Suppl. 10), 15-19. doi: 10.1111/j. 1600-051x.2009.01417.x

Tonetti, M. S., D'aiuto, F., Nibali, L., Donald, A., Storry, C., Parkar, M., et al. (2007). Treatment of periodontitis and endothelial function. N. Engl. J. Med. 356, 911-920.

Toregeani, J. F., Nassar, C. A., Nassar, P. O., Toregeani, K. M., Gonzatto, G. K., Vendrame, R., et al. (2016). Evaluation of periodontitis treatment effects on carotid intima-media thickness and expression of laboratory markers related to atherosclerosis. Gen. Dent. 64, 55-62.

Tsai, C. C., Chen, H. S., Chen, S. L., Ho, Y. P., Ho, K. Y., Wu, Y. M., et al. (2005). Lipid peroxidation: a possible role in the induction and progression of chronic periodontitis. J. Periodontal Res. 40, 378-384. doi: 10.1111/j.1600-0765.2005. 00818.x

Vidal, F., Figueredo, C. M., Cordovil, I., and Fischer, R. G. (2009). Periodontal therapy reduces plasma levels of interleukin-6, C-reactive protein, and fibrinogen in patients with severe periodontitis and refractory arterial hypertension. J. Periodontol. 80, 786-791. doi: 10.1902/jop.2009.080 471 
Wang, Y., Andrukhov, O., and Rausch-Fan, X. (2017). Oxidative stress and antioxidant system in periodontitis. Front. Physiol. 8:910.

Wehmeyer, M. M., Kshirsagar, A. V., Barros, S. P., Beck, J. D., Moss, K. L., Preisser, J. S., et al. (2013). A randomized controlled trial of intensive periodontal therapy on metabolic and inflammatory markers in patients With ESRD: results of an exploratory study. Am. J. Kidney Dis. 61, 450-458. doi: 10.1053/j.ajkd.2012.10. 021

White, P., Cooper, P., Milward, M., and Chapple, I. (2014). Differential activation of neutrophil extracellular traps by specific periodontal bacteria. Free Radic. Biol. Med. 75(Suppl. 1):S53.

Xue, F., Shu, R., and Xie, Y. (2015). The expression of NLRP3, NLRP1 and AIM2 in the gingival tissue of periodontitis patients: RT-PCR study and immunohistochemistry. Arch. Oral. Biol. 60, 948-958. doi: 10.1016/j. archoralbio.2015.03.005

Yagi, K. (1987). Lipid peroxides and human diseases. Chem. Phys. Lipids 45, 337-351. doi: 10.1016/0009-3084(87)90071-5

Yamaguchi, Y., Kurita-Ochiai, T., Kobayashi, R., Suzuki, T., and Ando, T. (2017). Regulation of the NLRP3 inflammasome in Porphyromonas gingivalisaccelerated periodontal disease. Inflamm. Res. 66, 59-65. doi: 10.1007/s00011016-0992-4
Yanbaeva, D. G., Dentener, M. A., Creutzberg, E. C., Wesseling, G., and Wouters, E. F. (2007). Systemic effects of smoking. Chest 131, 1557-1566. doi: 10.1378/ chest.06-2179

Zhou, Q. B., Xia, W. H., Ren, J., Yu, B. B., Tong, X. Z., Chen, Y. B., et al. (2017). Effect of intensive periodontal therapy on blood pressure and endothelial microparticles in patients with prehypertension and periodontitis: a randomized controlled trial. J. Periodontol. 88, 711-722. doi: 10.1902/jop.2017. 160447

Conflict of Interest: The authors declare that the research was conducted in the absence of any commercial or financial relationships that could be construed as a potential conflict of interest.

Copyright (c) 2021 Paul, Arora, Mayer and Chatterjee. This is an open-access article distributed under the terms of the Creative Commons Attribution License (CC BY). The use, distribution or reproduction in other forums is permitted, provided the original author(s) and the copyright owner(s) are credited and that the original publication in this journal is cited, in accordance with accepted academic practice. No use, distribution or reproduction is permitted which does not comply with these terms. 